\title{
Self-Disclosure of Adolescent Girls on TikTok Social Media
}

\author{
Henny Claresta ${ }^{1}$ Daniel Tamburian ${ }^{1 *}$
}

\author{
${ }^{1}$ Faculty of Communication, Universitas Tarumanagara, Jakarta 11440, Indonesia \\ *Corresponding author. Email: danielt@fikom.untar.ac.id
}

\begin{abstract}
Social media TikTok is a social media that is loved these days and in the usage often found individuals that conduct a self-disclosure. Self-disclosure on this social media is done by video that contain text, picture, or music. The purpose of this research is to know how self-disclosure of adolescent girls on TikTok social media. This research is using qualitative approach with descriptive research methods. Subject in this research are adolescent girls (age between 17-18 years old), and object in this research are self-disclosure on TikTok social media. This research is using the concept of self-disclosure and social media theory. Data collection method is done by interview, observation, documentation, and literature study. The results of this research are that individuals conduct a self-disclosure on TikTok social media in a descriptive and evaluative manner with the intention of expressing themselves, sharing experiences, and getting input from others. Factors that trigger individuals to conduct a self-disclosure on TikTok social media are a feeling of comfort and the presence of other individuals who do the same thing on this social media. In self-disclosure, individuals have a limitation of information shared on social media because there is a privacy that can't be disclosed.
\end{abstract}

Keywords: self-disclosure, adolescent girls, social media, TikTok

\section{INTRODUCTION}

Humans are basically social creatures whose lives cannot be separated from communicating and interacting with other people. This is done by humans as a fulfillment of the needs of life, get happiness, build relationships with others, and as a form of self-expression [1]. In interacting with other people, individuals often provide information about themselves to others or it can be called self-disclosure.

Over time, self-disclosure can not only be done by face-toface but also through social media. One of the social media that is so popular nowadays is TikTok social media. Based on data from the Sensor Tower Application Research Company in the year 2020 [2], the TikTok application has been downloaded 2 billion times on Android and IOS devices. TikTok's social media is so popular because of its feature that allows anyone to create short videos of 15-60 seconds in length accompanied by great music and editing features.

In the use of TikTok social media, individuals often do selfdisclosure through videos that include pictures, text, and music. Self-disclosure by individuals on social media usually contains personal information, that can less intimate and more intimate [3]. However, the problem is that individuals tend to use TikTok social media as a place to express themselves which consciously or unconsciously can have a positive or negative effect, considering that social media is a public space where there are people who do not

\begin{abstract}
know each other and peoples are free to express their opinion in this media.

As evidence of self-disclosure on TikTok social media, researchers took an example, namely a video from a TikTok account named @ nadiaaaa0203 which tells a personal story about him being liked by his own brother-in-law, until he was blasphemed by neighbors for admitting this to his brother. This shows the existence of self-disclosure on TikTok social media.

Talking about self-disclosure means talking about one's self-disclosure. Therefore, this study aims to determine how the self-disclosure of adolescents girl on TikTok social media, by using the concept of self-disclosure such as measuring openness using the Johari window and dimensions as well as seeing the functions and benefits of self-disclosure, as well as the factors that trigger selfdisclosure by adolescents girl on TikTok's social media. In addition, the author also uses social media theory in this study. The choice of teenagers themselves is because based on information from the Head of Public Policy of TikTok Indonesia, TikTok social media is widely used by users who are teenagers [4].
\end{abstract}




\subsection{Related Work}

\subsubsection{Presentation of Research Results by Muhammad Saifulloh and Maria Ulfah Siregar (2019)}

This research was conducted by Muhammad Saifulloh and Maria Ulfah Siregar with title "Gofar Hilman's Selfdisclosure as an Influencer on Instagram Social Media". This research was published in 2019 from Prof. Dr. Moestopo University. The purpose of this study was to determine the self-disclosure of Gofar Hilman as an influencer on Instagram social media and the relationship between Gofar Hilman as an influencer and self-disclosure as well as what things Gofar Hilman disclosed on Instagram social media and the reasons for disclosing these things.

This research uses qualitative research methods with constructivism paradigm and phenomenological methods. The concept / foundation in this research is the phenomenology theory of Alfred Schutz, Johari Window theory, the concept of new media and Computer Mediated Communication (CMC). Data collection using interviews and observations. The conclusion of this study shows that Gofar Hilman is more open to expressing his feelings related to the things he feels in order to release the burden and share the things he feels and to inspire.

\subsubsection{Presentation of Research Results by Ajeng Prima Dewi and Santi Delliana (2020)}

This research was conducted by Ajeng Prima Dewi and Santi Delliana with title "Generation Z Self-disclosure on Twitter". This research was published in 2020 from Communication Studies Program Faculty of Creative Industries, Institute of Technology and Business Kalbis Naskah. The purpose of this study was to determine how the form of self-disclosure of generation $\mathrm{Z}$ adolescents through the media twitter. The research method uses qualitative methods. Collecting data through interviews, observation, and literature study, and documentation.

The conclusion of this study is self-disclosure on Twitter in the form of emotions, anxiety, thoughts, and sadness where informants feel relieved by the support or support as a form of reply. Feelings of security and trust are also felt because they already know each other, the topic of self-disclosure is also limited, so as not to corner others and drop other people's names.

\subsubsection{Presentation of Research Results by Gisela Winy Massie and Eko Harry Susanto (2019)}

This research was conducted by Gisela Winy Massie and Eko Harry Susanto with title "Lesbian Self-Disclosure Through Facebook's New Media”. This research was published in 2019 on Journal Koneksi, Tarumanagara University. The purpose of this study is to describe the selfdisclosure of the lesbian minority on Facebook. This research was conducted with a descriptive qualitative approach through a case study research method for lesbians. The concept used is interpersonal communication and the concept of self-disclosure.

The conclusion of this study shows that with the presence of Facebook, lesbians can share their ideas, feelings, and anxieties even though basically this openness does not show their true identity.

\subsection{Our Contribution}

This research is expected to contribute to both academic and practical benefits. The academic benefits of this study are expected to be useful for the development of communication science, especially in the scope of the selfdisclosure of adolescent girls on TikTok social media and can be a reference for other researchers who want to research the self-disclosure of adolescent girls on TikTok social Media. The practical benefits of this study are expected to be a guide for communication practitioners in understanding adolescent girls self-disclosure on TikTok social media and the results of this study are expected to provide input for readers about the self-disclosure of adolescent girls on TikTok social media.

\subsection{Paper Structure}

The rest of the paper is organized as follows. Section 1 introduces the preliminaries used in this paper, which include background and problem formulation. Section 2 presents a theoretical framework and theories that used in this research Then, in Section 3 explain the methods that used in this research. Section 4 presents findings and discussion about the cases in this research. Finally, Section 5 concludes the conclusions of this research.

\section{BACKGROUND}

\subsection{Self-disclosure}

Self-disclosure theory comes from the great theory of interpersonal communication. Richard West and Lynn Turner in 2006 [3], define self-disclosure as a form of communication in the form of messages about oneself. Thus self-disclosure occurs when a person deliberately tells others something about themselves, which is not easy for others to know. DeVito [5], stated that the types of information conveyed in self-disclosure can vary from insignificant information or a low level of openness to a high level, the higher the level of openness, the more personal the information conveyed will be. According to Morton [6], self-information can be descriptive: individuals describe various facts about themselves that are not known to others, such as occupation, address, and age, evaluative: information related to an individual's opinion or personal feelings about something, such as the type of person they like or hate, explicit: personal information is more 
confidential because it is impossible for others to know, unless notified by the individual concerned.

\subsubsection{Johari Window Theory}

The johari window put forward by Joseph Luft and Harry Ingham [7], describes the level of openness of a person through four parts that show how individuals express and understand themselves as follows: Open area, shows people who are open to others, both person knows the information. Blind area, shows individuals who do not know many things about themselves but other people know more about them. Hidden area, shows individuals who know various things about themselves that are not known by others. Unconscious area, shows a situation where various things are not known by oneself and others.

\subsubsection{Dimension of Self-disclosure}

DeVito in 1997 [8], states that there are five dimensions of self-disclosure, as follows: Size or amount, is related to how much frequency and amount of information we disclose in conveying messages or it could be in a measure of time. Valence, related to the quality of self-disclosure, has a positive or negative impact. Honesty, is an important thing in self-disclosure. Sometimes self-disclosure is deliberately exaggerated so that it attracts the curiosity and sympathy of others. Purpose and objectives, occur when an individual will disclose what is intended to be disclosed, so that the individual can consciously control self-disclosure. Intimacy, related to the depth and breadth of self-disclosure. The more familiar we are with the recipient of the selfdisclosure message, the deeper the self-disclosure will be.

\subsubsection{Function of Self-disclosure}

There are five functions of self-disclosure according to Derlega and Grzelak [9] such as: Self expression, a person's expression of what he feels or it can be called the release of emotions. Self-purification, telling experiences or problems faced to others can clear and open minds so that they can see problems better. Social validity, seeing the responses or reactions of others when we do self-disclosure makes us get information about the accuracy of our views. Relationship development, sharing information and opening up can increase intimacy in a relationship. Social control, exposing or hiding information about ourselves as a means of social control. Devito also stated some of the benefits of selfdisclosure [10] such as: Self-knowledge, from selfdisclosure we can gain new perspectives and deep understanding of our behavior and ourselves. Ability to overcome difficulties, through self-expression and receiving support, not rejection, we are better equipped to deal with, reduce, even eliminate feelings of guilt and overcome adversity. Efficiency of communication, that is, a person understands messages from other people mostly, as long as we understand other people individually. Depth of relationships, through self-disclosure we tell others that we trust them, appreciate, and care for them and the existing relationship by revealing ourselves to them.

\subsubsection{Factors of Self-disclosure}

Effendi [10], stated several factors that influence selfdisclosure such as: The size of the group, self-disclosure occurs more in small groups than in large groups, The more people involved, the more difficult it will be because the responses will vary from different listeners. Feeling like, we open ourselves up to people we like or love, and we won't open ourselves up to people we don't like. The dyadic effect, a person doing self-disclosure when with people who do self-disclosure as well because it can make someone feel safer, and in fact reinforces self-disclosure behavior. Competence, someone who is competent, performs more self-disclosure than someone who is less competent. Personality, individuals who are good at socializing and extroverted more self-disclosure than individuals who are less sociable and introverted. Topic, a person is more likely to open up about work or hobby topics than about sex life or financial situations. Generally, the more personal and negative a topic is, the less we will reveal it. Gender, women tend to be more open than men, and to people they like while men are more open to people they trust.

\subsection{Social Media}

Social media is a means of communication based on internet technology (online) that allows a person to be able to social interact, communicate and collaborate, and share with other people [11]. Andreas Kaplan and Michael Haenlein [12], define social media as a group of internet-based applications that build on the foundation of Web 2.0 ideology and technology, and which enable the creation and exchange of user-generated content. According to Dijk [13], social media is defined as a media platform that focuses on the existence of users who facilitate them in activities and collaborations.

\subsubsection{TikTok}

TikTok is a social media platform that is now very popular and favored by the public. Based on information from the news portal Wartaekonomi, TikTok is a social media founded by Zhang Yiming, a man from China who also founded ByteDance. The TikTok application is known as Douyin in its home country and was inaugurated in September 2016. Based on information from the Sensor Tower Application Research Company in 2020, the TikTok application has been downloaded more than 2 million times on IOS and Android devices, where Indonesia alone contributed $11 \%$ of the total downloads [14]. In the TikTok application, each user can create videos that are less than 30 seconds long using unique and interesting special effects and provide music from various kinds of singers and genres that this application has provided, so that users can perform with various styles or dances, and still many more that can 
encourage the creativity of its users as content creators. The videos that have been made can then be shared and can be seen by other TikTok users [15]

\subsection{Public Relations}

Bertrand Russel Chanfield [16], stated that the purpose of public relations is an activity to instill and gain understanding, goodwill, trust, appreciation in and from the public or society in general. Along with the times, the internet has made PR people use online media, in the world of internet character and a person's reputation can be seen by anyone. According to Onggo [17], Cyber Public Relations or E-PR is a public relations initiative that uses the internet as a means of publicity. Cyber public relations can certainly be linked to a person's self-disclosure through social media. Through cyber public relations, individuals who perform self-disclosure can produce what is called $3 \mathrm{R}$ such as: Relations, it's mean to be able to interact with various target audiences to build relationships and images. Reputation, cyber public relations is an art in building an online reputation on an ongoing basis. Relevance, public relations activities carried out have relevance to individual public targets [18]. Therefore, self-disclosure on TikTok social media is related to cyber public relations in terms of how a person can build his image, reputation and relationship on social media by telling or showing information related to themselves to others which can have an impact on the individual themselves.

\section{METHODS}

This study uses a qualitative approach. Qualitative research is research that has the aim of gaining an in-depth understanding of social and human problems by interacting with phenomena. This research does not use data that can be measured statistically, the aim is to explain the findings clearly in detail to answer the problem formulation. The research method used in this study is descriptive method. The descriptive method aims to describe, summarize various conditions, various situations, or various social reality phenomena that exist in society that are the object of research, and attempt to draw that reality to the surface as a feature, character, nature, model, sign, or description of certain conditions, situations, or phenomena [19]. The object of this research is self-disclosure on TikTok social media, and the subject are adolescent girls (age between 1718 years old). The data collection process carried out by the author is by conducting interviews with three informants, namely Putri Mariesca, 17 years old with 3,5K followers and has used TikTok for 2 years, Farah Bhakti, 17 years old with $591 \mathrm{~K}$ followers and 4 years of using TikTok, and Novita Putri Regina, 18 years old with as many followers. $14.8 \mathrm{~K}$ and have been using TikTok for approximately 1 year. The next method are, non-participant observation by observing the TikTok social media, documentation, and also using literature study to collect data. The validity technique used in this study was triangulation, namely triangulation of sources by comparing the results of interviews and data that had been collected in harmony or not. Data analysis using stages from Miles \& Huberman, such as data reduction, data presentation, drawing conclusions and verification.

\section{FINDINGS AND DISCUSSIONS}

TikTok social media is a social media that is so popular nowadays because of the interesting features it provides and in its use each individual can create short videos with duration of 15-60 seconds that can be accessed by anyone who uses TikTok. In the use of TikTok social media, individuals often find doing self-disclosure. According to Jourard in 1971 [6], self-disclosure is a form of communication where a person consciously provides information related to themselves or personally to others. Devito [5], also said that the higher the level of openness in the information provided, the more personal the information provided would be, and vice versa. Based on the results of interviews and observations of researchers on the TikTok accounts of the three sources who are teenage girls, the researcher saw that self-disclosure carried out on TikTok social media was packaged in the form of video stories or confidences accompanied by pictures or photos, text, and music. The three sources stated that in providing personal information or telling stories related to personal matters on TikTok social media, they usually focused more on topics related to their's feelings, or something related to life problems they faced. In addition, they also share stories related to experiences they have had on TikTok social media. According to Morton [6], there are three characteristics of self-information in self-disclosure, namely descriptive, evaluative, and explicit. Judging from the self-disclosure made by the three sources, it shows that the nature of self-disclosure carried out is more evaluative, it's mean that the information conveyed is related to an individual's opinion or feeling about something. However, the nature of self-information can also be descriptive because individuals tell experiences or feelings by describing them in the form of stories or texts in the form of facts related to the individual herself. Personal information can also be a bit confidential or explicit because this information can be known by others if the individual themselves tells.

\subsection{Dimensions of Adolescent Girl Self- disclosure on TikTok Social Media}

Devito divides the dimensions of self-disclosure into five dimensions, the first is the size or amount, this is related to the frequency of self-disclosure that is carried out. Based on the results of the interview, the researcher found that the individual did self-disclosure only when he wanted to or was influenced by the individual's mood. The second is valence, this is related to the quality of self-disclosure itself. Based on information from the informants, in selfdisclosure, they tend to provide positive information. However, the impact of self-disclosure cannot be predicted whether it will have a positive or negative impact, 
considering that everyone's opinion is different so that according to them, even though it is positive, there are still people who do not believe or judge it negatively. This means that the assessment related to self-disclosure depends on the thoughts and opinions of each individual who sees it. The third is honesty, based on information from the sources, they admit that in telling stories or confiding in personal matters, they are always honest and in accordance with their real life, even though there are some videos that they deliberately exaggerate to make it more interesting, but still stick to reality that they actually experienced. When associated with public relations, in the dimensions of valence and honesty, individuals have acted in accordance with the principles of public relations, namely showing things or information that are positive and being honest. Where in public relations, being honest is something that must be done.

The fourth is the intent and purpose, based on the information from the informants, they do self-disclosure to release emotions and tell experiences because they want to do it, as well as to get input and inform others what they do consciously so that they themselves control what they want be delivered.

And the last is intimacy, based on information from the sources, they admit that in telling their personal things they still limit things, not too openly but not too closed. What they think can be conveyed they convey, but what they think is something that cannot be conveyed they will not tell. This means that they will not convey things that are too personal in self-disclosure, considering that TikTok social media is a medium that is very much in public consumption, selfdisclosure also has its limits.

\subsection{Functions or Benefits of Adolescent Girls Self-disclosure on TikTok Social Media}

Based on the results of interviews with the three sources, researchers found that individuals telling stories or confiding on TikTok social media is a form of selfexpression or to release the emotions or feelings and burdens they feel. In addition, individuals also feel relieved after telling stories on TikTok social media. This is related to the self-clarification function where after telling the problems experienced, the individual gets clarity of mind and a feeling of relief arises.

Individuals often feel that there are no friends to talk to or confide in so they decide to tell stories on TikTok social media and from them telling stories on TikTok, they see many people who experience similar things with them, as well as support in the form of comments from viewers that make them feel happy at once relieved, so that they are more courageous in expressing themselves. This is also related to the benefits of self-disclosure proposed by Devito, namely that self-disclosure helps individuals to overcome difficulties.

The function of social validity can also be seen from the self-disclosure of the three sources, where individuals tell their experiences or problems they have experienced, then find many responses from people who feel the same way.
Through these responses, individuals get information and input from others that can help them so that they also get new perspectives about themselves. This shows that individuals can indirectly know themselves better, in accordance with the benefits of self-disclosure stated by Devito, namely self-knowledge.

Social control function, where individuals have control over what they want to share. Individuals tend to be more daring to tell things that can have a positive impact and get support and tend to hide things that might cause controversy or bad responses.

In addition, by sharing their experiences or feelings on TikTok social media, individuals feel closer to their viewers and followers because of their mutual support and motivation. But it does not rule out, individuals still feel that their relationship with viewers is limited to those who watch themselves and not those who are very close to them. That means, by telling stories about themselves or opening up with other people on TikTok social media can create relationship development, individuals can be better known and also know their followers. This is related to public relations, where self-disclosure by individuals on TikTok social media can produce what is called $3 \mathrm{R}$ in cyber public relations, one of which is relations. This means that by doing self-disclosure, individuals can build relationships with other people.

\subsection{Factors that Trigger Adolescent Girls Self- Disclosure on TikTok Social Media}

The first factor is the size of the group, even though TikTok is a medium that is widely used by people and the videos uploaded by the speakers tend to have a lot of views, they still feel comfortable doing self-disclosure on TikTok social media. This is because according to them other TikTok users are not judgmental like other social media and people in here tend to be open-minded. So that individuals feel comfortable and feel more free to express themselves on social media even though the number of groups is said to be quite large.

The second factor is the feeling of liking, individuals feel comfortable expressing themselves on TikTok social media because of their liking for the social media. They feel that TikTok social media is a fun social media with the various features it provides and the interactions made with the people in it are able to make individuals feel comfortable and close.

The third factor is the dyadic effect, self-disclosure made by the informants is also influenced by the self-disclosure made by other people on TikTok social media, which sources often encounter when using social media. In addition, the existence of comments from other people who feel the same way often makes individuals more courageous in expressing themselves.

The fourth factor is competence, in making self-disclosure on TikTok social media, individuals admit that this is not done to pursue views or likes. However, seeing the number of views or likes you get when making self-disclosing 
videos will have a little influence on individuals to be more daring to express themselves on TikTok social media.

The last factor is the topic, based on the results of the study, researchers found that individuals prefer topics that can be said to be less negative and general, for example related to sadness, anxiety, or life problems that have relevance to the lives of most people. Besides that, it is also topics related to experiences that can provide messages to others.

\subsection{Johari Window Analysis of Adolescent Girls Self-disclosure on TikTok Social Media}

The johari window, according to Joseph Luft and Harry Ingham [7], consists of four spaces or areas, namely open, closed, blind, and unconscious areas. These areas show a person's openness. Open area, is an area where both parties know the existing information. Based on the results of the study, the researcher saw that this area was increasingly open or enlarged because of the information conveyed by the source about herself which was later known by others, meaning that they both knew the information.

The blind area is an area where other people know the individual better than the individual herself. Based on the results of the study, the researchers found that this area experienced a slight shift or was slightly enlarged, because individuals unconsciously show things related to themselves which are then accepted by others as a form of information related to the individual. Such as, how to dress, body movements, which may not be realized by individuals but become information for others.

Hidden areas, namely areas known only to the individual herself. Based on the results of research on informants, the researcher found that this area experienced the most enlargement or shift compared to other areas. This is because in self-disclosure on TikTok social media, individuals still have limitations. They stated that before uploading something on TikTok social media, they also processed or sorted the information to be conveyed. If that is too private, they will keep it. This means that in expressing themselves on TikTok social media, there are still many things they hide because it is a privacy that cannot be shared with others.

Unconscious areas, namely areas that are not known by individuals or others. Based on the research results, this area has not experienced a shift or enlargement. This is because in expressing themselves, individuals consciously know what they share and what they share is what other people know. Therefore, the researchers did not see a link between the self-disclosure of adolescent girls on TikTok social media and this unconscious area, because the information shared by individuals is clearly known by the individual herself and others only know the information shared by the individual.

Based on the results of this study, the researcher described the Johari window regarding the self-disclosure of adolescent girls on TikTok social media as in the picture below.
Picture 1. Johari Window Analysis of Adolescent Girls Self-disclosure on TikTok Social Media

\begin{tabular}{|c|c|}
\hline OPEN AREA & $\begin{array}{c}\text { BLIND } \\
\text { AREA }\end{array}$ \\
\hline HIDDEN \\
AREA & $\begin{array}{c}\text { UNCONSCIOUS } \\
\text { AREA }\end{array}$ \\
& \\
\hline
\end{tabular}

\section{CONCLUSIONS}

The conclusions of this research are:

The nature of self-disclosure carried out by the three sources who are adolescent girls is more evaluative, meaning that self-disclosure is in the form of expressions of feelings. In addition, self-disclosure is also descriptive, because individuals provide descriptions related to problems or experiences they have experienced.

The frequency of self-disclosure that is done quite often depends on the mood of the individual. The quality of selfdisclosure that is carried out can have a positive or negative impact depending on the opinion of everyone who sees it. In conducting self-disclosure, individuals are honest and aim to tell stories, release emotions, share experiences, and get input from others. Self-disclosure that is carried out also has limitations and is not too intimate.

The functions and benefits of individuals from selfdisclosure on TikTok social media are to express themselves, get relief, share experiences, get support and motivation for themselves and others.

The factor that most triggers individuals to conduct selfdisclosure on TikTok social media is a feeling of comfort because TikTok users are considered not judgments. In addition, the large number of other users who conduct selfdisclosure on TikTok social media, encourages individuals to do the same.

Self-disclosure of adolescent girls on TikTok Social Media in the johari window shows that hidden areas have the largest space because there is still a lot of information hidden by individuals in revealing themselves, and open areas also experience enlargement because individuals share information related to themselves so that it is known by others.

\section{ACKNOWLEDGMENT}

The author would like to thank all those who have helped and encouraged the author during the writing of this thesis, among others, Mr. H.H. Daniel Tamburian who has guided the author, the three informants who are ready to be interviewed, the author's parents and friends from Tarumanagara University Faculty of Communication. 


\section{REFERENCES}

[1] D. Mulyana, Ilmu Komunikasi: Suatu Pengantar. Bandung: PT Remaja Rosdakarya, 2012.

[2] "TikTok Crosses 2 Billion Downloads After Best Quarter For Any App Ever," 2020. [Online]. Available: https://sensortower.com/blog/tiktok-downloads-2billion. [Accessed: 01-Dec-2020].

[3] R. Loisa and Y. Setyanto, Penyingkapan Diri Melalui Internet Di Kalangan Remaja (Studi Komunikasi Antar Pribadi), Jurnal Komunikasi Untar, vol. 6, no. 3, pp. 3143, 2014.

[4] I. Rakhmayanti, Pengguna TikTok di Indonesia Didominasi Generasi Z dan Y, Sindonews.com, 2020. [Online]. Available: https://autotekno.sindonews.com/ berita/1523692/207/pengguna-tiktok-di-indonesiadidominasi-generasi-z-dan-y. [Accessed: 01-Oct-2020].

[5] Y. Tania, Self-disclosure Anak yang Pindah Agama kepada Orang Tua, E-Komunikasi, vol. 4, no. 1, pp. 112, 2016.

[6] M. B. Gainau, Keterbukaan Diri, Sekolah. Tinggi Agama Kristen Protestan Negeri Papua, pp. 12-36, 2012.

[7] T. Budiaraharjo and T. Kartika, Komunikasi Antarpribadi dan Komunikasi Kelompok Tenaga Pengamanan Perambah Hutan Illegal untuk Mengatasi Perambahan Hutan, J. Chem. Inf. Model., vol. 53, no. 9, pp. 1689-1699, 2019, doi: 10.1017/ CBO9781107415324.004.

[8] G. J. Setiadi, Self-disclosure individu androgini melalui instagram sebagai media eksistensi diri, Jurnal Studi Komunikasi (Indonesian J. Commun. Stud., vol. 3, no. 2, p. 272, 2019, doi: 10.25139/jsk.v3i2.1497.

[9] F. Yz-zahra and N. Hasfi, Studi Fenomenologi Online Self-disclosure melalui Instagram Story, Jurnal Interaksi Online, vol. 7, no. 1, pp. 56-67, 2018.

[10] Kudratullah, Self-disclosure Waria Terhadap Teman Wanita (studi kasus di pasar Masomba Palu), Jurnal KInesik, vol. 7, no. 1, pp. 37-48, 2020.

[11] I. A. Ratnamulyani and B. I. Maksudi, Peran Media Sosial Dalam Peningkatan Partisipasi Pemilih Pemula Dikalangan Pelajar Di Kabupaten Bogor, Sosiohumaniora, vol. 20, no. 2, pp. 154-161, 2018, doi: 10.24198/sosiohumaniora.v20i2.13965.
[12] A. S. Cahyono, Pengaruh media sosial terhadap perubahan sosial masyarakat di Indonesia, Jurnal ilmu Sosial ilmu Politik diterbitkan oleh Fak. Ilmu Sos. Polit. Univ. Tulungagung, vol. 9, no. 1, pp. 140-157, 2016.

[13] A. Sagiyanto and N. Ardiyanti, Self-disclosure Melalui Media Sosial Instagram (Studi Kasus Pada Anggota Galeri Quote)," Nyimak (Journal Commun., vol. 2, no. 1, pp. 81-94, 2018, doi: 10.31000/ nyimak.v2i1.687.

[14] W. K. Pertiwi, Indonesia Sumbang Angka Unduhan TikTok Terbanyak di Dunia, Kompas.com, 2020. [Online]. Available: https://tekno.kompas.com/read/ 2020/09/11/15010037/indonesia-sumbang-angkaunduhan-tiktok-terbanyak-di-dunia.

[15] S. Susilowati, Pemanfaatan Aplikasi Tiktok Sebagai Personal Branding Di Instagram (Studi Deskriptif Kualitatif Pada Akun @bowo_allpennliebe), Jurnal Komunikasi, vol. 9, no. 2, pp. 176-185, 2018, doi: 10.31294/jkom.v9i2.4319.

[16] F. Nurtjahjani and M. Trivena, Public Relation, Citra dan Praktek. Malang: Polinema Press, 2018.

[17] A. Basit and T. H. Rahmawati, Cyber Public Relations (E-PR) dalam Brand Image Wardah Kosmetik dengan Pedekatan Mixed Method, Nyimak (Journal Commun., vol. 1, no. 2, pp. 197-208, 2018, doi: 10.31000/nyimak.v1i2.483.

[18] G. A. E. B., Strategi Cyber Public Relations dalam Pembentukan Citra Institusi Pendidikan Tinggi Swasta, J. Messenger, vol. 6, no. 1, p. 1, 2016, doi: 10.26623/themessenger.v6i1.161.

[19] B. Bungin, Penelitian Kualitatif. Jakarta: Kencana, 2017. 